Article

\title{
The Growth and Development of Sweet Basil (Ocimum basilicum) and Bush Basil (Ocimum minimum) Grown under Three Light Regimes in a Controlled Environment
}

\author{
Mohammed Aldarkazali, Hail Z. Rihan *, Demelza Carne and Michael P. Fuller(D) \\ School of Biological and Marine Sciences, University of Plymouth, Plymouth PL4 8AA, UK; \\ mohammed.aldarkazali@plymouth.ac.uk (M.A.); demelza.carne@plymouth.ac.uk (D.C.); \\ mfuller@plymouth.ac.uk (M.P.F.) \\ * Correspondence: hail.rihan@plymouth.ac.uk; Tel.: +44-7513724273
}

Received: 15 October 2019; Accepted: 6 November 2019; Published: 11 November 2019 updates

\begin{abstract}
Light is a crucial element for plant growth and production. In areas where natural light is not sufficient for optimal plant growth and production, high pressure sodium (HPS) light sources are widely used. However, HPS lamps are considered not very electrically efficient generating high radiant heat and as a consequence, there has been a lot of interest in replacing HPS lamps with new more efficient lighting sources in the form of light-emitting diodes (LEDs). The effects of three lighting sources (White LED, Blue/Red LED and HPS) on the growth, development and on the essential oil yield and quality of sweet basil and bush basil were investigated. There was a clear advantage to the Blue/Red (452 nm and $632 \mathrm{~nm}$, respectively) LED on virtually all growth and physiological parameters measured for both basil species. The HPS lighting system always performed least effectively in all comparisons. Combining increases in plant yield and increases in oil yield the Blue/Red LED array outperformed the HPS lights by a factor of approximately double, with the white LED being intermediate between these two extremes.
\end{abstract}

Keywords: LEDs (light-emitting diodes); high-pressure sodium lamps (HPS); basil; essential oil; photosynthesis; light spectrum

\section{Introduction}

Ocimum basilicum L. (Basil) belongs to the Lamiaceae family and grows wild in tropical and sub-tropical climates [1]. Basil is an important culinary herb and essential oil crop grown and used worldwide [2,3] and basil essential oil has been used widely in the food industry as a food flavor, in the medical industries [4], as a component of oral health and dental products and also in the fragrance industry [5]. Moreover, basil has been claimed to be effective in treating several medical complaints such as anxiousness, stomach aches, pyrexia, kidney failure, arthropod stings, sickness, infections, headaches, coughs, and constipation [5-9]. Basil 1 is used as flatus-relieving medicine for gastrointestinal disorders and found to increase milk production in nursing mothers [10].

Basil essential oils contain a wide array of chemical compounds, depending on genotype and growing conditions (light, temperature, and irrigation) [11]. The main active organic biochemical components of basil essential oils are; estragole, a phenylpropene used in perfume manufacturing and as a food additive for flavor $[12,13]$ and linalool, which is used widely as a scent in many hygiene products and cleaning agents [14].

Plants do not utilize all wavebands of white light (sunlight) equally but those between $400-700 \mathrm{~nm}$ provide photons of the correct energy to drive photosynthesis and these wavelengths are typically 
referred to as Photosynthetically Active Radiation (PAR) [15-17]. Other wavebands are also important in photo-morphological development (above $700 \mathrm{~nm}$ ) and in causing damage to plant cell DNA (below $400 \mathrm{~nm}$ ) [18].

In high latitudes, especially in the northern hemisphere, warm climate crops such as tomatoes, cucumbers and peppers are grown under protected cropping in glasshouses or poly-greenhouses and supplementary lighting is necessary in order to maintain sustainable rates of growth and production, especially in the winter when natural daylight is limited [19]. High-pressure sodium (HPS) lamps are currently the most commonly used source of supplementary lighting. High-pressure sodium (HPS) lamps emit light over a broad, unmodifiable spectrum of wavelengths but with high peaks in the PAR region. They emit a high degree infrared radiation leading to thermal emission and raising leaf and air temperature and this also reduces the efficiency of these lamps in terms of electrical cost for PAR generation. The heat production from HPS lamps has been found to have a negative effect on plant development [20].

Recently, LED arrays have surpassed HPS lights in terms of the electrical cost per photon [21,22] and now LED arrays have a potential for use in agricultural/horticultural production [23]. light-emitting diodes (LEDs) have a linear photon output with the electrical input current. LEDs are gaining in substantial importance in plant growth industries not only because LEDs can be constructed in arrays large enough to provide sufficient PAR while remaining small in size (few centimeters in diameter) but also emit less heat than HPS lighting lamps [20,24-26]. LEDs are also known for their durability and long operating lifetime (Dickinson, 2007). Wavelength specificity of LED's is accomplished via changes in chemical makeup of the semiconducting material used [27]. An increasing body of research is reporting the role of LEDs in enhancing the shape, edible quality [28], biomass, number of leaves [29], growth and stem width and other traits of various plant species [30].

Since individual LEDs only emit low levels of light, arrays of several to hundreds are constructed to boost the overall light output of lighting devices. Furthermore, each individual LED has a narrow waveband, the construction of arrays provides the manufacturers of lighting devices with an almost infinite combination of different LEDs to produce a unit with a very specific overall wavelength pattern. Many researchers across the world are experimenting with different unit arrays in order to determine which LED combinations are most useful as a supplementary or as a sole source light for plant growth.

The current research aimed to compare three commercially available lighting units: HPS, full Spectrum LED and Blue/Red LED used as sole source lighting, on the growth and physiological parameters including: plant height, leaf area, fresh and dry weight, stomatal conductance, maximum photosynthesis rate, and chlorophyll fluorescence ratio (as a measure of photosynthetic efficiency)) of two species of basil: Sweet basil and bush basil. Moreover, it aimed to investigate the effect of these lighting units of the quantity and quality of essential oil from sweet basil.

\section{Materials and Methods}

Sweet basil (Ocimum basilicum) and bush basil (Ocimum minimum) seeds were obtained from Suttons seeds Ltd. (UK). Four replicate pots per species were used in each light treatment and with two experimental replications. The treatments were set up in a controlled environment (CE) room divided into three compartments and the treatments randomly allocated to the compartments. In the experimental repeat, the treatments were re-randomized to the compartments. The pots $(9 \times 9 \mathrm{~cm})$ used in the experiment were filled with $250 \mathrm{~g}$ of compost (John Innes No.1) and four seeds were sown in each pot. After sowing the seeds, each pot was watered with $1000 \mathrm{~mL}$ of water. The pots were randomly distributed within each compartment. Temperature and humidity were monitored using Gemini data loggers (Tinytag Plus, No GP-1590, Chichester, UK). The air temperature in the CE room had a set-point of $28^{\circ} \mathrm{C}$. The dark/light period was set to $8 \mathrm{H}$ dark/16 $\mathrm{H}$ light. The three-light units used were: High-Pressure Sodium lamp (HPS) (Omega, Barry, UK), White (full spectrum) LED (W LED) (Skyline 400, LED Hydroponics, Berkshire, UK) and Blue/Red (BR) lighting LED (Mars Hydro, Mars II 1600, Shenzhen, China). Light intensity for all of the lighting units (HPS, W LED, and BR LED) was 
monitored and adjusted using a Skye PAR quantum sensor (Skye Instruments, Powys, UK) to provide $470 \pm 20 \mu \mathrm{mol} \mathrm{m}^{-2} \mathrm{~s}^{-1}$ at the upper surface of the plant pots. The light spectra were recorded using an UPRtek MK350N premium stand-alone handheld spectral light spectrometer (Figure 1). The HPS lamp showed a broad spectrum of wavelengths with the main radiation peak at $596 \mathrm{~nm}$ yellow, W LED showed three main wavelength peaks; $451 \mathrm{~nm}$ Blue, $550 \mathrm{~nm}$ Green, and $620 \mathrm{~nm}$ Red with a significant amount of light distributed in the Green region whilst the BR LED had two main peaks at $459 \mathrm{~nm}$ Blue and $632 \mathrm{~nm}$ Red.

Growth and physiological parameters were measured at two stages of development; at the maximum leaf development stage (40 days after sowing) and at full flowering stage (54 days after sowing) (harvest 1 and harvest 2 ). The plants were continuously monitored and irrigated when needed. Extra air circulation had to be provided to plants grown under HPS light unit to maintain the same temperature as other treatments because of heat gain from the lamp and this meant that more frequent irrigation was needed in these pots. Plants were grown for a total of 48 days.

Physiological measurements included; light-saturated instantaneous maximum photosynthetic rate Amax $\left(\mu \mathrm{g} \mathrm{cm}^{-2} \mathrm{~s}^{-1}\right)$ measured using an LCi-SD Highly Portable Ambient Photosynthesis System (ADC BioScientific, Herts, UK); the chlorophyll fluorescence ratio ( $\mathrm{Fv} / \mathrm{Fm}$ ) measured using a Hansatech Pocket PEA meter (Hansatech Ltd., Norfolk, UK); stomatal conductance (Gs mmol m${ }^{-2} \mathrm{~s}^{-1}$ ) measured using a Delta-T AP4 Leaf Porometer (Delta T Devices, Cambridge, UK).

Morphological measurements included; plant height $(\mathrm{cm})$ from the compost surface to the top of the plants; leaf area LA $\left(\mathrm{mm}^{2}\right)$, using leaf an area image analyser HITACHI KP-D40 colordigital camera with a lightbox and WinDias 1.5 software (Delta-T Devices Ltd, Cambridge, UK); fresh weight (FW) and dry weight (DW) (g) after removing the root system, using a sensitive Fisher Scientific SG-402 laboratory balance; plants were dried at $60{ }^{\circ} \mathrm{C}$ for $96 \mathrm{~h} \mathrm{[31].}$

HPS
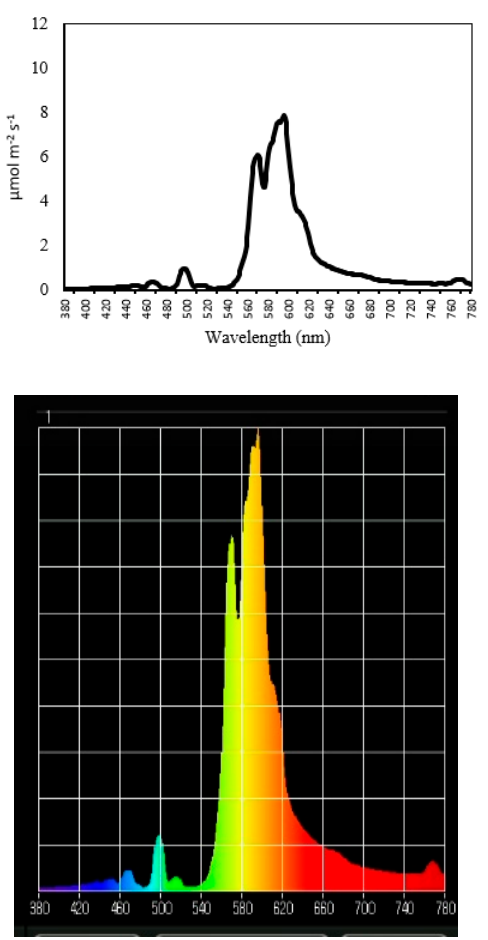

RB LED

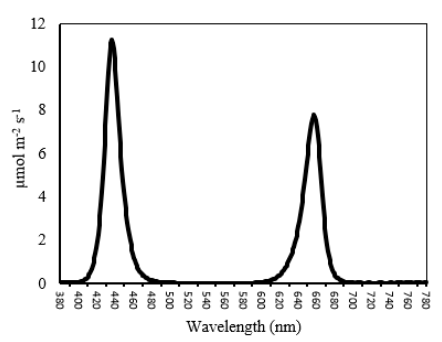

(A)

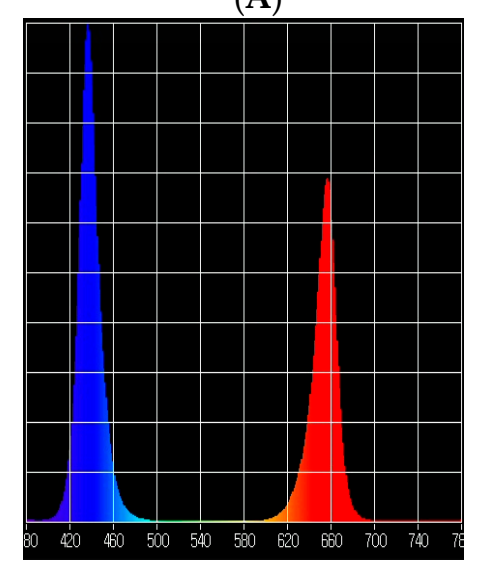

(B)
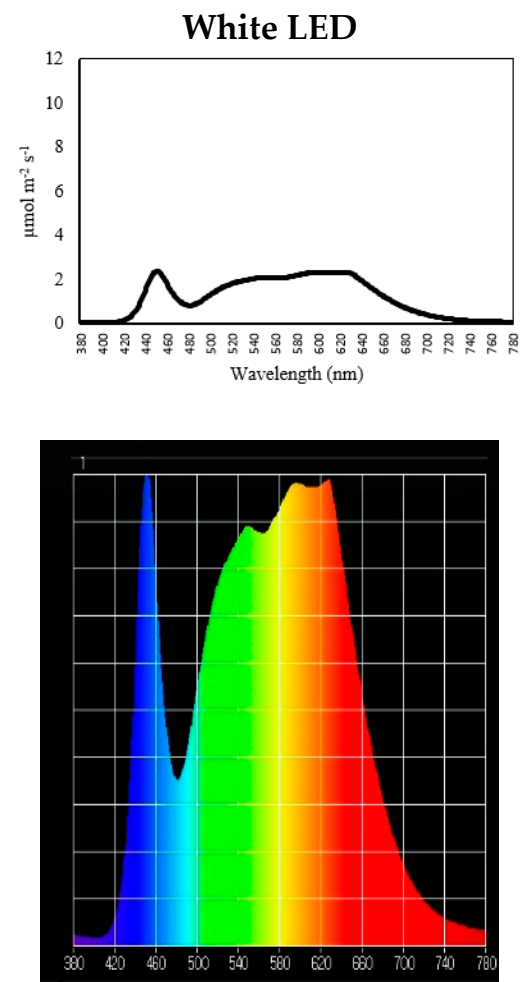

Figure 1. Spectra of the lighting units used as measured by UPRtek. (A) The radiant density of the light spectrum intensity. (B) The relative light intensity. 


\subsection{Chemical Analysis}

Dry plant material (stems and leaves) was used to extract the essential oil from sweet basil using a solvent extraction method [32] with some modifications. Dry plant material (20 g) was ground in a mortar and pestle with $10 \mathrm{~mL}$ of FISHER Scientific's HPLC grade C6H14 (hexane) $\geq 95 \%$ (Thermos Fisher Scientific, Gloucester, UK). The resultant mixture was then added to a sintered column with the addition of $60 \mathrm{~mL}$ of Hexane. The mixture was then drained and the solution collected. A significant amount of the hexane was evaporated using a BÜCHI R-124 Rotary Evaporator System. A blow-down technique using thermal Techne $₫ S a m p l e$ Concentrator and BOC Nitrogen gas was applied to evaporate the remainder of the hexane from the solution [33]. The essential oils of sweet basil were then collected in a vial. The vial was weighed after the blow-down to calculate the quantity of the essential oil obtained.

\subsection{Gas Chromatography (GC)}

Five main components of basil essential oil, according to their common appearance in the literature [34-36] and their industrial importance [37], were isolated and measured: estragole $\mathrm{C}_{10} \mathrm{H}_{12} \mathrm{O}$, eugenol $\mathrm{C}_{10} \mathrm{H}_{12} \mathrm{O}_{2}$, (Ethyl) E-cinnamate $\mathrm{C}_{11} \mathrm{H}_{12} \mathrm{O}_{2}$, eucalyptol $\mathrm{C}_{10} \mathrm{H}_{18} \mathrm{O}$, and linalool $\mathrm{C}_{10} \mathrm{H}_{18} \mathrm{O}$.

Reference samples of the five compounds were obtained from SIGMA-ALDRICH with a purity of $\pm 99 \%$ and a diluted solution was prepared to a concentration of $250 \mathrm{mg} \mathrm{mL}^{-1}$ with hexane to be compatible with the gas chromatograph (GC) and were used as standards for the GC analysis. GC analysis was conducted according to the procedure of Chenni et al. and Kumari et al. [38,39]. The GC was performed using a 7890B Gas Chromatograph System. The essential oil of sweet basil $(0.025 \mathrm{~g})$ was added to $10 \mathrm{~mL}$ hexane to make a stock solution. A working solution was then prepared by adding 1 $\mathrm{mL}$ of the stock solution to $9 \mathrm{~mL}$ of hexane. A solution of 1-1.5 $\mathrm{mL}$ was added to GC vial.

Stock solutions of the reference samples were prepared using the same procedure: $0.1 \mathrm{~mL}$ of each stock solution of each chemical (five chemicals in total) added together in a single GC vial to give a total of $0.5 \mathrm{~mL}$. Then $0.5 \mathrm{~mL}$ of hexane was then added to the GC vial to make a final test solution of 1 $\mathrm{mL}$ solution of $250 \mathrm{mg} \mathrm{mL}^{-1}$ concentration.

A solution of 1-1.5 mL hexane was added to each GC vial and then analyzed using an Agilent Gas Chromatograph 7890A equipped with a 7683 Series Autosampler and 7683B Series Auto-injector (Agilent, Santa Clara, CA, USA) and HP5 Column, 5\% phenyl-95\% dimethylsiloxane, low polarity column, $30 \mathrm{~m} \times 0.320 \mathrm{~mm}$ i.d., and $0.25 \mu \mathrm{m}$ film thickness. The carrier gas was nitrogen at a flow rate $=$ $1.0 \mathrm{~mL} \mathrm{~min}{ }^{-1}$, Injector temperature was $250{ }^{\circ} \mathrm{C}$, Flame Ionization Detector temperature was $300{ }^{\circ} \mathrm{C}$, Hydrogen flow rate was $40 \mathrm{~mL} \mathrm{~min}^{-1}$, Airflow rate $=400 \mathrm{~mL} \mathrm{~min}^{-1}$, Nitrogen (make-up) flow rate $=$ $15 \mathrm{~mL} \mathrm{~min}^{-1}$. General Method temperature was programmed at $40-300^{\circ} \mathrm{C}$ at $10^{\circ} \mathrm{C} \mathrm{min}^{-1}, 10 \mathrm{~min}$ at $300^{\circ} \mathrm{C}$ using ChemStation software (Revision B.03.01, May 2007).

\subsection{Statistical Analysis}

Results are presented as means \pm standard error (S.E.). All data were subjected to analysis of variance (ANOVA) using Minitab software (version 17) and comparisons of means were made using the least significant difference test (LSD) at $5 \%$ level of probability.

\section{Results}

\subsection{Physiological Responses}

\subsubsection{Maximum Photosynthetic Rate $A_{\max }$}

There was a significant effect of the lighting treatments on the light-saturated instantaneous maximum photosynthetic rate $\mathrm{A}_{\max }$ of sweet basil $(p=0.005)$ and bush basil $(p=0.001)$. The highest $\mathrm{A}_{\max }$ was observed in plants grown using BR LED lights at both harvest stages. There was no significant impact of the harvest stage and there was no interaction between the lighting treatments and harvest stages on the $\mathrm{A}_{\max }$ (Figure 2). 


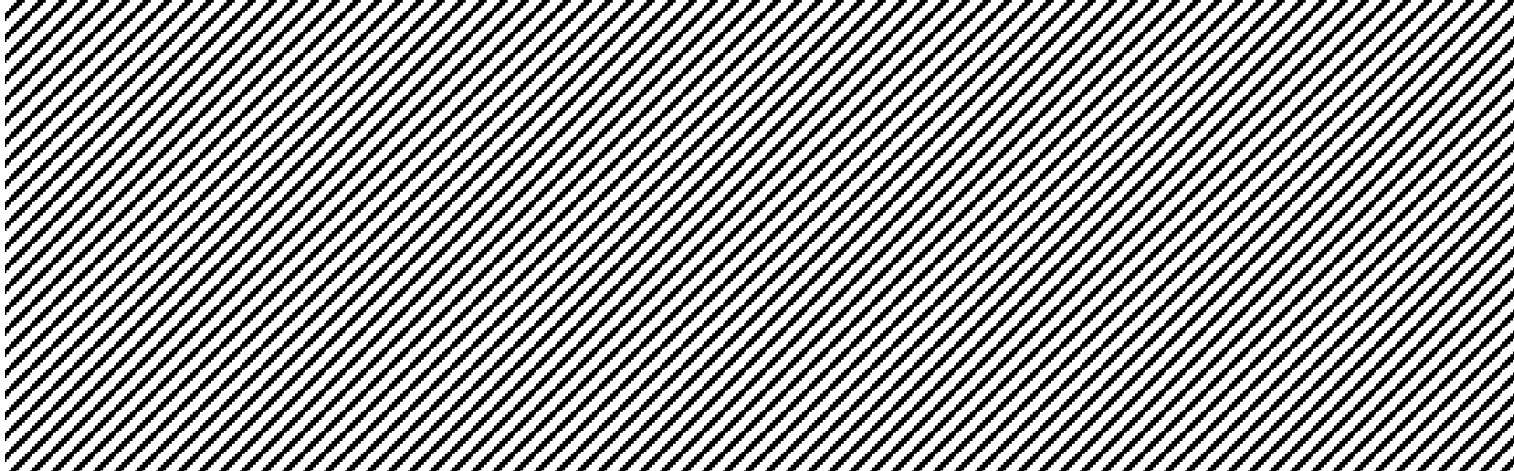

Figure 2. The effect of light treatments and harvest stage on the maximum photosynthetic rate $\mathrm{A}_{\max }$ of sweet basil (LSD $=0.87$ for light treatment) and bush basil (LSD $=0.87$ for the light treatment). Different letters denote significant differences $(p<0.001)$.

\subsubsection{Stomatal Conductance Gs}

There was a significant effect of light treatments and harvest stage on the stomatal conductance Gs in sweet and bush basil $(p \leq 0.001)$. Moreover, there was a significant interaction between the light treatments and harvest stage on Gs for both plant species. The highest Gs was observed under the BR LED lighting unit at both harvest stages and in both plant species (Figure 3).
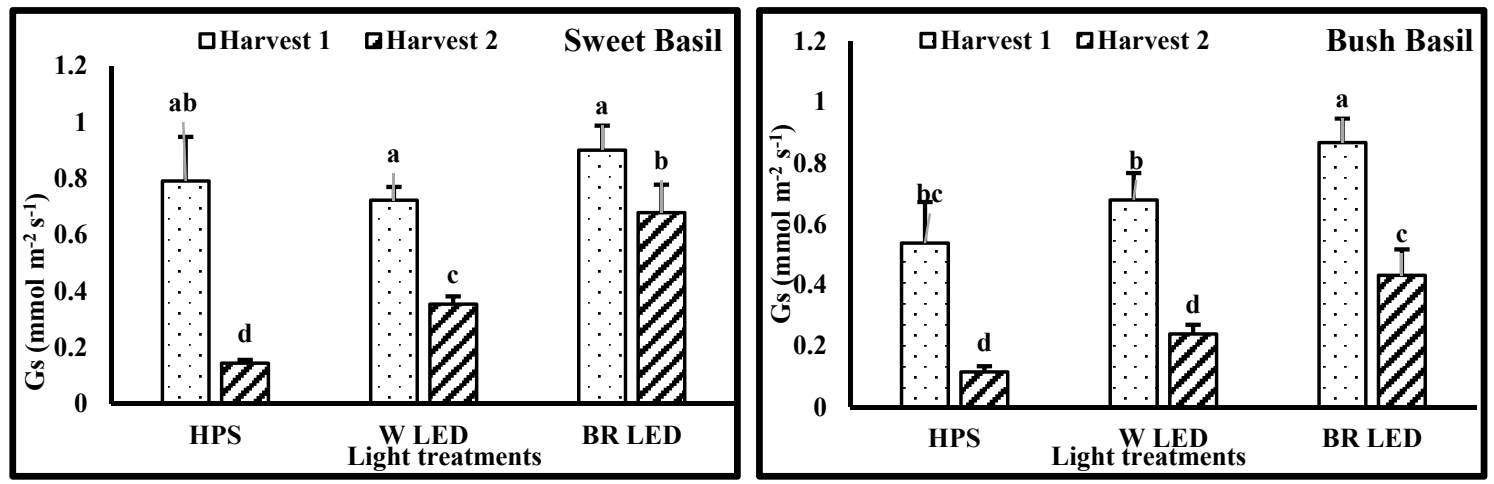

Figure 3. The effect of light treatments and harvest stage on the stomatal conductance Gs in sweet basil (least significant difference test $(\mathrm{LSD})=0.144$ for the light treatment, LSD $=0.118$ for the harvest stage and LSD $=0.204$ for the interaction between light treatments and harvest stage) and bush basil (LSD $=0.13$ for the light treatments, $\mathrm{LSD}=0.11$ for the harvest stage). Different letters denote significant differences between treatments. $(p<0.05)$.

\subsubsection{Chlorophyll Fluorescence Ratio Fv/Fm}

There was a significant effect of the light treatments on the chlorophyll fluorescence rate $\mathrm{Fv} / \mathrm{Fm}$ for sweet basil $(p=0.001)$ but not for bush basil $(p=0.1)$. The highest $\mathrm{Fv} / \mathrm{Fm}$ was observed in plants grown under the BR LED light treatment in sweet basil for both harvest stages (Figure 4). There was a significant effect of the harvest stage on Fv/Fm in bush basil $(p=0.02)$ and Fv/Fm at the first harvest was significantly higher than at the second harvest. However, for sweet basil, the harvest stage had no significant effect on $\mathrm{Fv} / \mathrm{Fm}(p=0.2)$. 

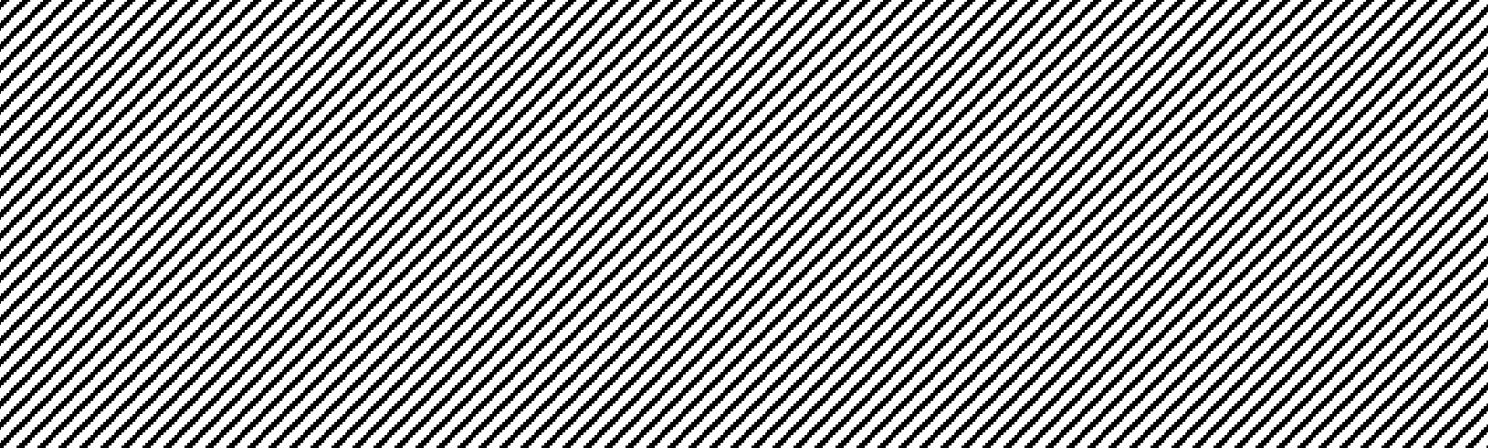

Figure 4. The effect of light treatments and harvest stage on the chlorophyll fluorescence rate Fv/Fm in sweet basil (LSD $=0.042$ for the light treatments) and bush basil (LSD $=0.05$ for the harvest stage). Different letters denote significant differences between treatments $(p<0.05)$.

\subsection{Morphological Responses}

\subsubsection{Height}

There was no significant effect of the light treatments on plant height in both sweet and bush basil. The harvest stage has a significant effect on the plant height $((p \leq 0.001)$ with taller plants observed at harvest stage two (Figure 5).
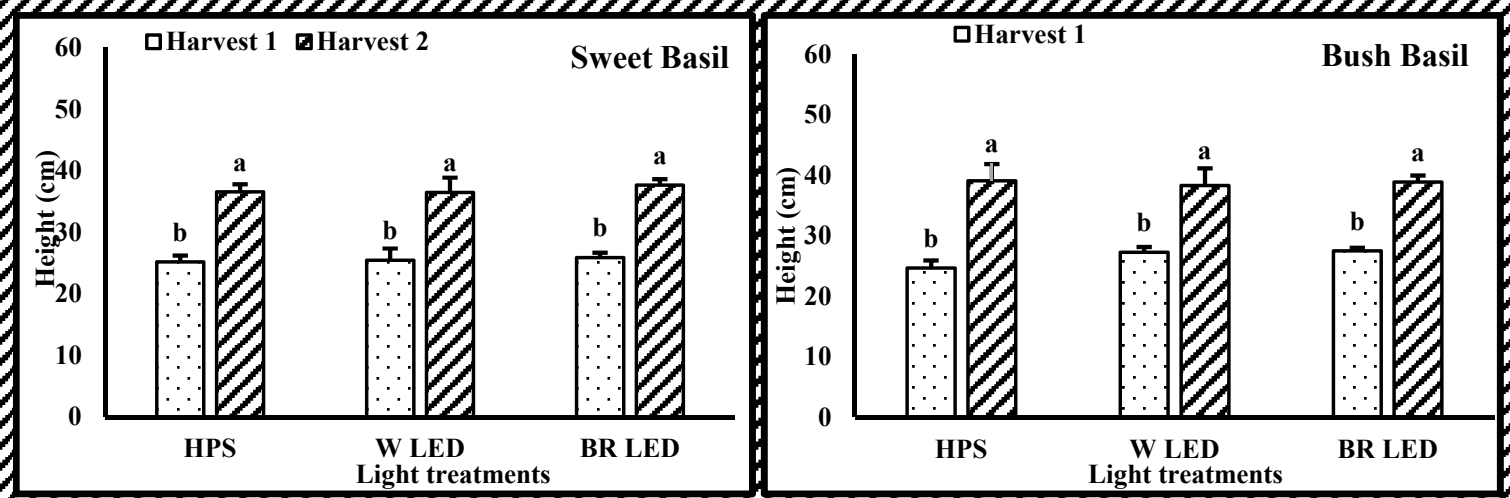

Figure 5. The effect of light treatments and harvest stage on the height of sweet basil (LSD $=2.06$ for the harvest stage) and bush basil (LSD $=2.4$ for the harvest stage). Different letters denote significant differences between treatments $(p<0.01)$.

\subsubsection{Leaf Area LA}

In sweet basil, there was a significant effect of the light treatments and harvest stage on the leaf area LA $(p \leq 0.001)$. The optimum LA was observed in plants grown under the BR LEDs at both harvest stages for both species. For bush basil, there was a significant effect of the light treatments $(p=0.02)$ on LA and plants cultivated under BR LEDs showed larger leaf area per ground surface area unit. LA was significantly higher $(p \leq 0.001)$ at harvest stage two in both plant species (Figure 6). 

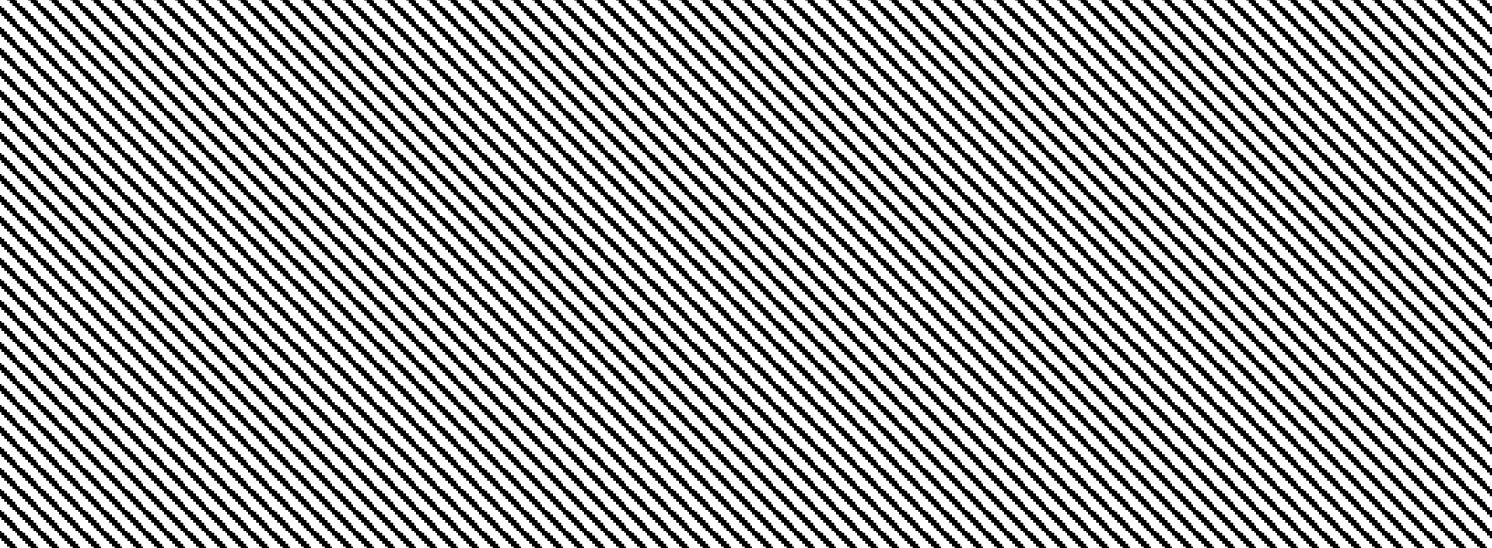

Figure 6. The effect of light treatments and harvest stage on the leaf area LA in sweet basil (LSD = 663.1 for the light treatments, LSD $=541.4$ for the harvest stage) and bush basil (LSD $=68.4$ for the light treatments, $\mathrm{LSD}=55.9$ for the harvest stage and LSD $=96.8$ for the interaction between light treatments and harvest stage). Different letters denote significant differences between treatments $(p<0.001)$.

\subsubsection{Fresh Weight (FW)}

There was a significant impact of light treatments on the fresh weight FW of sweet basil $(p=0.006)$. The maximum FW was observed in plants grown under BR LED lighting unit at both harvest stages for both plant species. There was a significant effect of the harvest stage $(p \leq 0.001)$ on FW. At harvest stage two FW was significantly higher in comparison with harvest stage one for both Sweet and bush basil.

In terms of bush basil, there was a significant interaction between light treatments and harvest stage $(p=0.01)$. While the highest fresh weight was observed in plants grown under White LEDs at harvest stage one, FW was highest in plants grown under BR LEDs at harvest stage two (Figure 7).
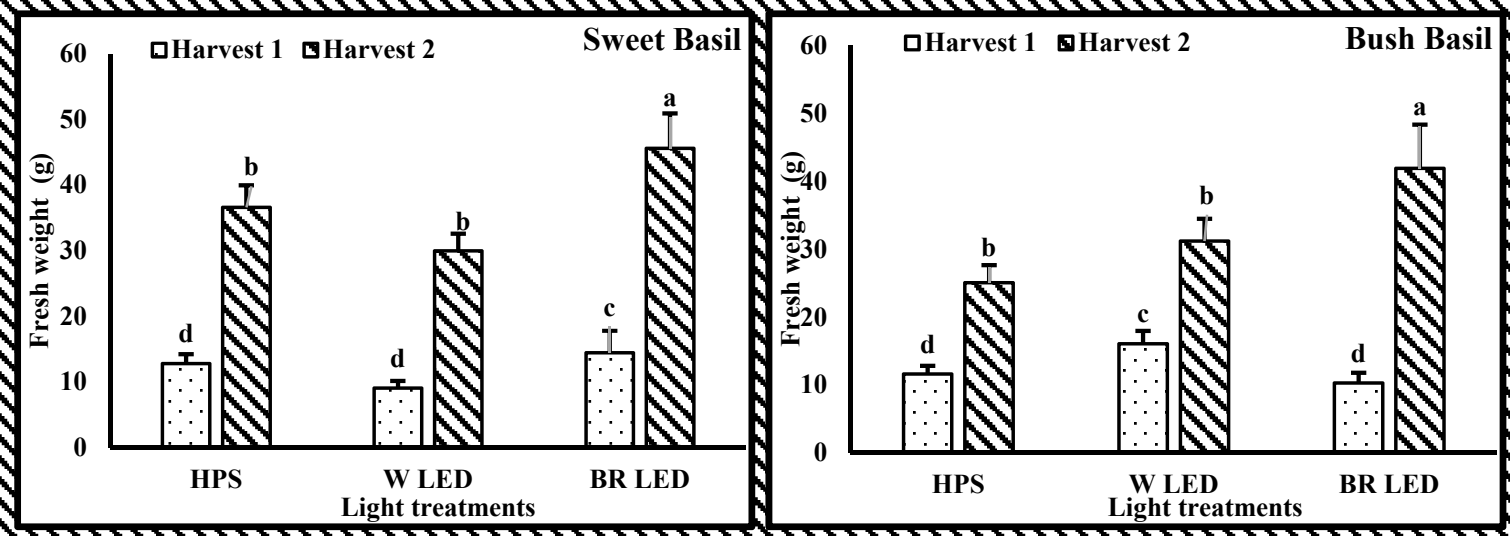

Figure 7. The effect of light treatments and harvest stage on plant fresh weight fresh weight (FW) of sweet basil (LSD = 5.2 for the light treatment, $\mathrm{LSD}=4.3$ for the harvest stage) and bush basil (LSD $=4.4$ for the harvest stage and LSD $=7.7$ for the interaction between the light treatments and harvest stage). Different letters denote significant differences between treatments $(p<0.001)$.

\subsubsection{Dry Weight DW}

There was no significant impact of the light spectrum on DW of sweet basil but there was a significant effect on bush basil ( $p=0.001$ ) under BR LEDs (Figure 8). 


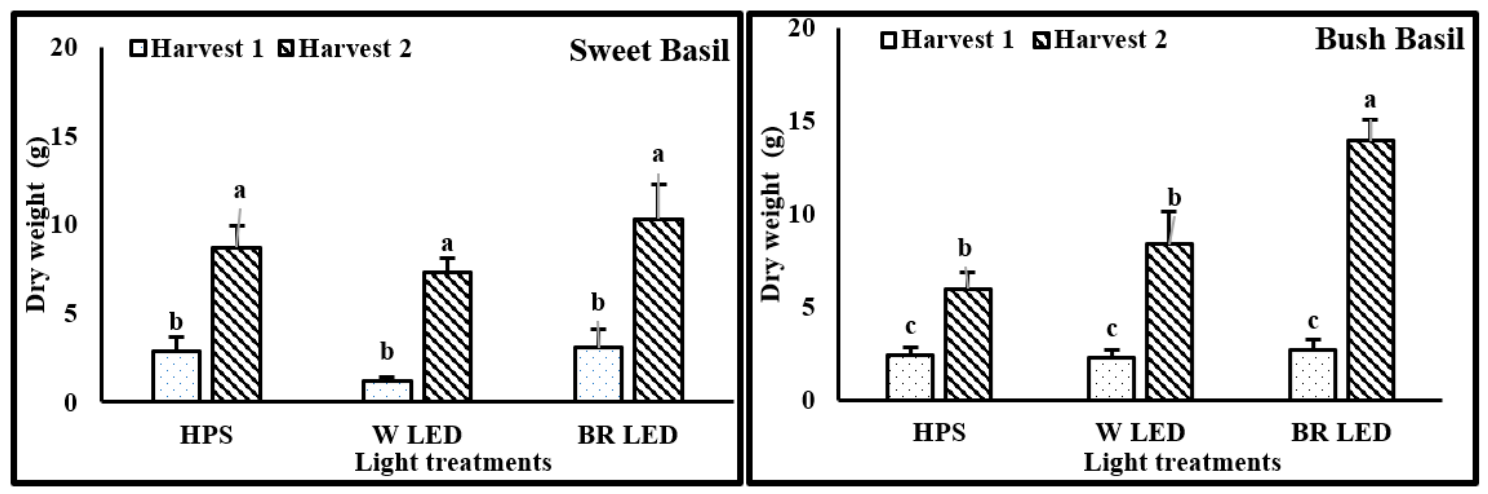

Figure 8. The effect of light treatments and harvest stage on plant dry weight DW of sweet basil (LSD $=1.5$ for the harvest stage) and bush basil (LSD = 1.6 for the lighting treatment, LSD = 1.3 for the harvest stage and LSD $=2.3$ for the interaction between the lighting treatments and harvest stage). Different letters denote significant differences between treatments $(p<0.001)$.

The harvest state had a significant impact on DW for both plant species and was significantly higher at harvest stage two.

\subsubsection{Essential oil Yield and Composition}

Light treatments had a significant impact on the yield of essential oil in sweet basil $(p=0.005)$. The highest essential oil yield was observed in plants cultivated under BR LEDs (Figure 9).

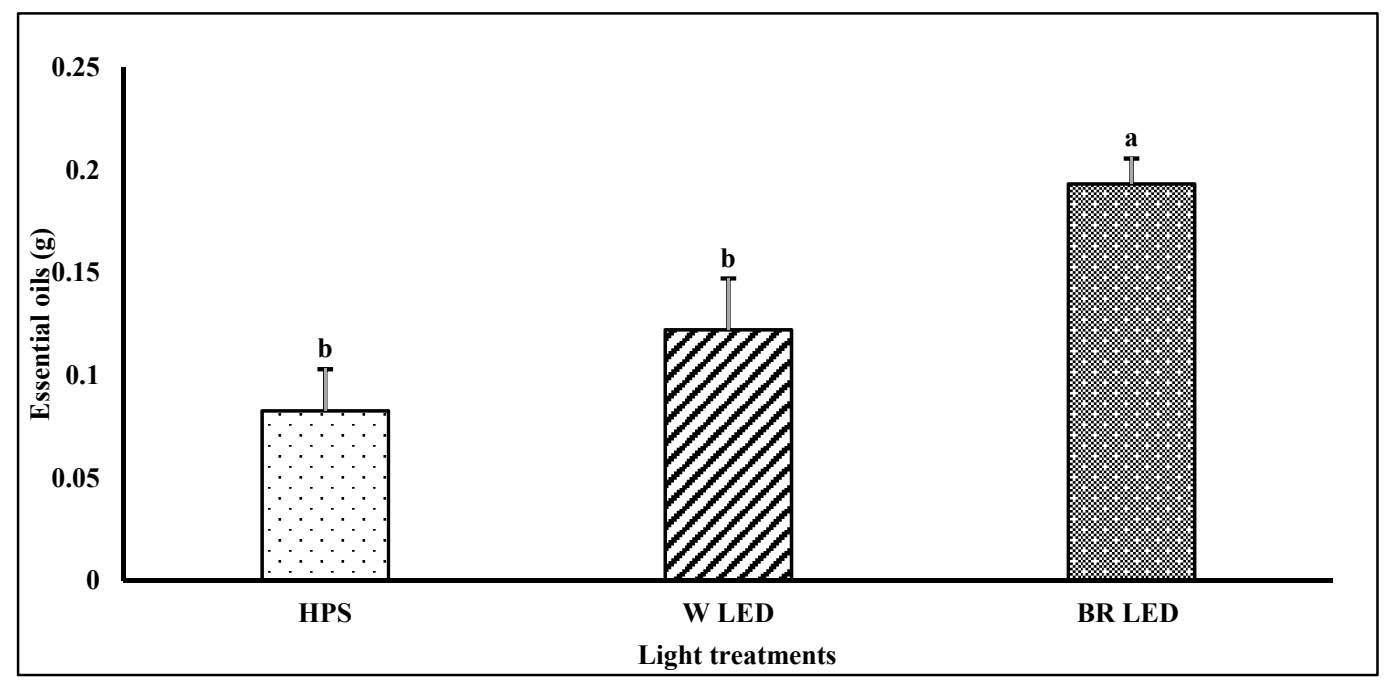

Figure 9. The effect of light treatments on the yield of essential oil in sweet basil (LSD $=0.049)$. Different letters denote significant differences between treatments $(p<0.001)$.

Results from the Gas Chromatography analysis showed that LED lighting significantly improved the accumulation of linalool, Eugenol and E-Cinnamate in the essential oil of sweet basil compared to the accumulation of those biochemicals in the essential oil of plants grown under HPS lamp. Moreover, BR LEDs significantly increased the concentration of Eucalyptol in contrast with both White LED and HPS lights (Figure 10). 


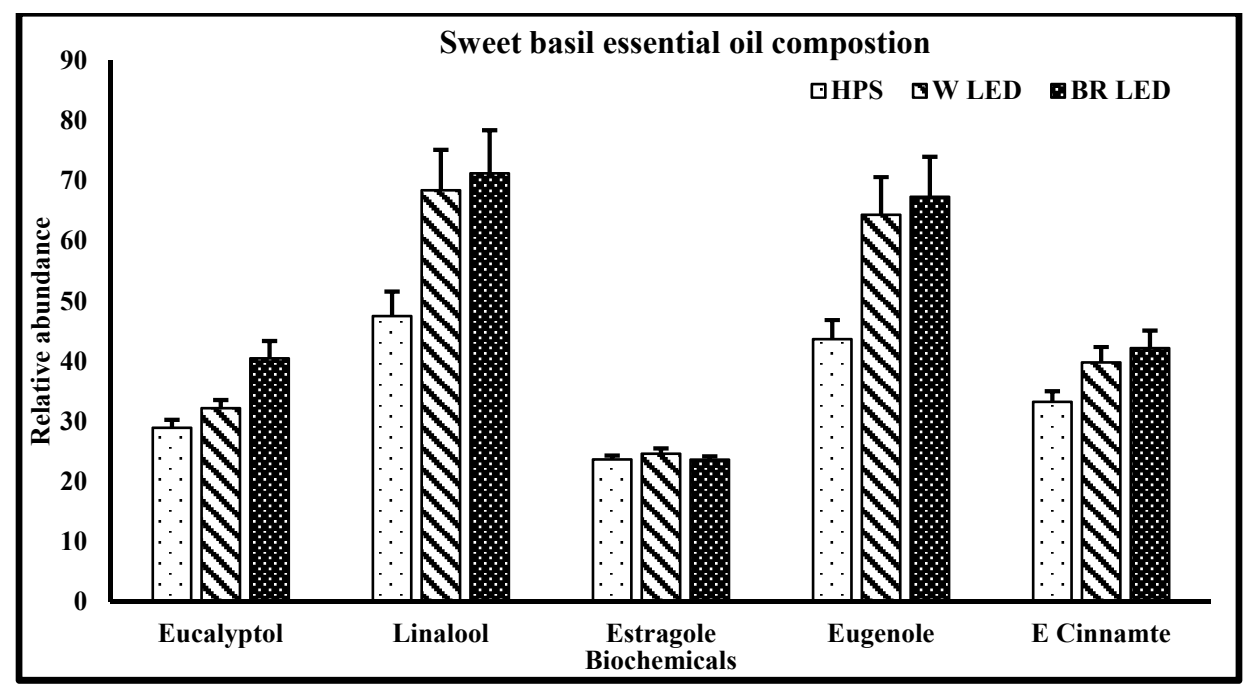

Figure 10. The effect of light treatments on the composition of essential oil in sweet basil (LSD = 17.3 for the lighting treatment). Relative abundance shows the average intensity of biochemical signals.

\section{Discussion}

This study clearly demonstrated that different lighting systems with the same PAR output but with different spectral profiles can influence the growth and yield of basil plants and the yield of essential oil. This correlates well with several other studies [40-43]. A consistent and strong trend can be observed through all of the results in favor of LED arrays in comparison to HPS lights and in favor of the BR LED in comparison to the White LED array. The physiological measurements made indicated that photosynthesis was more productive under the LED arrays with higher Amax and $\mathrm{Fv} / \mathrm{Fm}$ and this appears to have resulted in greater leaf area production leading to greater growth and yield. Gaining this sort of knowledge of plants growth and morphology in response to lighting changes gives a better understanding of more efficient cultivation of these plants. In particular, controlled environment cultivation of plants increases the chances of enhancement and uniformity in yield and quality but standard controlled conditions for each plant species needs to be carefully optimized. [44]. Precise regulation of environmental control in commercial controlled environments can be considered to still be in its early stages since each plant species may have a different response to different light quality and spectra, photoperiods and light integrals as it passes through its developmental stages.

These considerations must be observed when switching the cultivation of plants from field to any indoor farming unit and monitoring the photosynthetic activity is an important tool to achieve that goal. Mimicking the sunlight energy efficiency is not an easy task but has been established that the effect of Red light in the region of 650-665 nm from LED lighting units matches the assimilation peak of the photoreceptors phytochrome and chlorophyll. It was shown also, that the combination of Red-Blue light in LED lighting for growing plants, can enhance the Maximum Photosynthetic rate Amax as a consequence of activation of Cryptochromes, Phytochromes and Chlorophyll more than if a monochromic light was used as a grow light. [45]. This increase in Amax was explained as a result of the increase in carbon dioxide levels when the Blue light caused a better stomatal gapping [46-48]. The addition of Blue LED light in the region (380-495 nm) also stimulates Chlorophyll and is also found to trigger Cryptochromes influences stem growth. This correlates with the results presented here where it was found that Gs was higher under BR LED. This increase in Amax and Gs thus leads to an increase in DW with the addition of Blue light. The value of Amax can respond to the Red light (peak $656 \mathrm{~nm}$ ) more than a response to a White LED light [49]. On the other hand, it was found that there is a negative effects of the addition of Green LED light $(495-570 \mathrm{~nm})$ on the growth and development of plants which supports our findings as White LED and HPS lighting (contain some Green spectrum) promoted lower values of growth than those plants under BR LED light (no green light). Curiously, 
PAR is defined to include all wavelengths between 400 and $700 \mathrm{~nm}$ which of course includes green light which is not very photosynthetically active. This challenges the set-up of experiments designed to compare lighting units with each other. If for example, as used here, the PAR is set to be similar under all light units, by the above definition, those containing green light will be proportionately lower in the required red and blue light. Such considerations may require a re-examination of the instruments used to measure light in LED lit controlled environments with a possible move away from Quantum Sensors towards Spectrometers which can measure specific wavelength intensities more accurately.

In the process of photosynthesis, Photosystem II (PS II) light-dependent chemical reaction productivity rate $(\mathrm{Fv} / \mathrm{Fm})$ can be measured as an indication of a healthy plant [50,51]. Fv/Fm is a normalized ratio created by dividing variable fluorescence by maximum fluorescence. It is a measurement ratio that represents the maximum potential quantum efficiency of Photosystem II when all reaction centers are open [51]. Fv/Fm is sensitive to the light conditions and therefore lower values of $\mathrm{Fv} / \mathrm{Fm}$ can indicate stress via photo-inhibition. Fv/Fm is related to the quantum yield in PS II as other studies have shown similar results where Blue LEDs increased photochemical quenching whilst Red LEDs enhanced chlorophyll content despite chloroplasts being smaller [52]. The current analysis has shown that a combination of Blue $(459 \mathrm{~nm})$ and Red $(632 \mathrm{~nm})$ LED lights can promote a higher $\mathrm{Fv} / \mathrm{Fm}$ than HPS or white LED lights of the same PAR output. Moreover, Fv/Fm was around 0.8 (optimal) even at harvest stage two using the BR LEDs (Figure 2) whereas it had diminished to less than optimal under the other light treatments. This is an indication that the BR LEDs provides suitable conditions for efficient photosynthetic activities to persist at late growth stage of the plant $[45,53,54]$.

The effects of light quality on photosynthesis go parallel with the effect on stomatal gapping. It has been established that Blue region of the spectrum has more impact on the stomatal opening than Red light $[55,56]$. Both of these studies showed the low impact of green light on stomatal opening. Red and blue wavelengths are both utilized during photosynthesis by chlorophyll and secondary pigments, therefore promoting growth and development in plants [52,54]. A recent study sought to un-pick the influences of Red and Blue light on growth and photosynthetic efficiency in sweet basil and found that quantum efficiency in PSII was lower under Red/Blue LED light arrays when the Red portion of the light array was greater than double the Blue (2:1). This was reversed when light ratios were more equal (1:1) [57]. It is the presence of the Photosystem II Primary Donor protein P680 in PSII which absorbs maximum light energy at $680 \mathrm{~nm}$ (Red) and Photosystem I Primary Donor P700 in PSI which absorbs maximum light energy at $700 \mathrm{~nm}$ (Red) and these might be responsible for the effects on the stomatal conductance Gs [58-60]. In the current study, the ratio of Blue; Red in BR light treatments was higher than the ratio of Blue; Red in both White LED and HPS lighting units. This could explain the high Gs value results under BR LED as a response to the high Blue; Red ratio.

An increase of Blue light had a positive effect on lettuce a negative impact on soybean and wheat [61]. In contrast, sweet basil was positively affected by Blue light when measuring FW (at $200 \mu \mathrm{mol} \mathrm{m} \mathrm{m}^{-2} \mathrm{~s}^{-1}$ ) and when the same light quality compared with low light intensity (at $100 \mu \mathrm{mol} \mathrm{m} \mathrm{m}^{-2} \mathrm{~s}^{-1}$ ) the FW value was lower indicating the importance of combinations of wavelengths and quantity to promote high yielding plants [62]. Light has a relationship with FW of plant material and it has been found that Blue light (455-475 nm) with light intensity $\left(140 \pm 10 \mu \mathrm{mol} \mathrm{m}^{-2} \mathrm{~s}^{-1}\right)$ resulted in high FW [63].

The highest LA value was observed under Blue/Red lighting treatments in comparison with both white LED and HPS lighting units. In agreement with current findings, the light spectrum of $580 \mathrm{~nm}$, $600 \mathrm{~nm}$ was reported to inhibit the growth and development of leaves in Lettuce leading to a low value of LA [64]. However, in disagreement with the current research, it was reported that an increase of Blue light $455 \mathrm{~nm}$ by $6.7 \mu \mathrm{mol} \mathrm{m}{ }^{-2} \mathrm{~s}^{-1}$ over $400 \mu \mathrm{mol} \mathrm{m}{ }^{-2} \mathrm{~s}^{-1}$ for $20 \mathrm{~h}$ decreased the LA of tomato (Solanum lycopersicum) and Cucumber (Cucumis sativus) [65]. The difference in plant heights and LA response to light quality could be due to the effect of plant species and experimental conditions.

Alongside the main photo-related photosynthesis reaction, a phenyl-based anabolism reaction accrues in plant species resulting in organic matter that gives plants their specific aroma and taste. Many research reports have indicated the impact of light quality on the essential oils of plant species [66-69] 
and the current data agrees that light composition has an effect on the quantity and quality of essential oil of sweet basil. BR LED regime had a significant positive impact on the quantity and quality of essential oil extracted from sweet basil and this might alter the taste these plants. In another study, the essential oil content of basil grown under Blue light has been found to be up to four times higher than those grown without Blue light [66]. This is in agreement with our findings where BR LEDs had a positive impact on the level and concentration of important biochemicals in the essential oil of sweet basil.

\section{Conclusions}

Light quality had an impact on the physiological and growth characteristics of sweet basil and bush basil. LEDs lighting devices had an advantage in promoting high yielding plants with a higher concentration of essential oil compared to traditional HPS lamps. There was a clear advantage of using a Blue-Red LED lighting unit (452 nm Blue $632 \mathrm{~nm}$ Red) compared to a white LED unit; this research could have a great practical application for the commercial production of basil in sole source-controlled environments. Further research is recommended to determine more precisely the optimal wavelength of light in both the Blue and Red regions and the optimal Blue/Red combination for the growth of and production of basil.

Author Contributions: M.A.: conducted the laboratory experiments; H.Z.R.: supervised M.A. thorough the laboratory experiments, helped with results and statistical analysis and writing up the manuscript; D.C. helped in running the laboratory experiments. She also helped in revising the manuscript; M.P.F.: The research took place in Mick Fuller plant physiology laboratory. M.P.F. helped in supervising the whole research. He also helped in writing up the manuscript and proof-reading the English.

Funding: This research was part funded by the European Regional Development Fund for Cornwall, UK under an AgriTech research grant, the Seale-Hayne Educational Trust (Grant RR204307) and by the author (Mohammed Aldarkazali) as part of a self-funded Research Masters course at the University of Plymouth, UK.

Acknowledgments: Technical assistance is gratefully acknowledged from Claire Williams (Senior Laboratory Technician, University of Plymouth).

Conflicts of Interest: The authors declare no conflict of interest. "The funders had no role in the design of the study; in the collection, analyses, or interpretation of data; in the writing of the manuscript, or in the decision to publish the results".

\section{References}

1. Makri, O.; Kintzios, S. Ocimum sp. (basil): Botany, Cultivation, Pharmaceutical Properties, and Biotechnology. J. Herbs Spices Med. Plants 2008, 13, 123-150. [CrossRef]

2. Dube, S.; Upadhyay, P.; Tripathi, S. Antifungal, physicochemical, and insect-repelling activity of the essential oil of Ocimum basilicum. Can. J. Bot. 1989, 67, 2085-2087. [CrossRef]

3. Hossain, M.A.; Kabir, M.; Salehuddin, S.; Rahman, S.M.; Das, A.; Singha, S.K.; Alam, M.K.; Rahman, A. Antibacterial properties of essential oils and methanol extracts of sweet basil (Ocimum basilicum) occurring in Bangladesh. Pharm. Biol. 2010, 48, 504-511. [CrossRef] [PubMed]

4. Simon, J.E.; Quinn, J.; Murray, R.G. Basil: A source of essential oils. In Adv. New Crops; Janick, J., Simon, J.E., Eds.; Timber Press: Portland, OR, USA, 1990; pp. 484-489.

5. Kathirvel, P.; Ravi, S. Chemical composition of the essential oil from basil (Ocimum basilicum Linn.) and its in vitro cytotoxicity against HeLa and HEp-2 human cancer cell lines and NIH 3T3 mouse embryonic fibroblasts. Nat. Prod. Res. 2012, 26, 1112-1118. [CrossRef] [PubMed]

6. Dasgupta, T.; Rao, A.; Yadava, P. Chemomodulatory efficacy of basil leaf (Ocimum basilicum) on drug metabolizing and antioxidant enzymes, and on carcinogen-induced skin and forestomach papillomagenesis. Phytomedicine 2004, 11, 139-151. [CrossRef] [PubMed]

7. Holm, Y. Bioactivity of basil. In Basil; CRC Press: Boca Raton, FL, USA, 1999; pp. 117-139.

8. Lee, S.-J.; Umano, K.; Shibamoto, T.; Lee, K.-G. Identification of volatile components in basil (Ocimum basilicum L.) and thyme leaves (Thymus vulgaris L.) and their antioxidant properties. Food Chem. 2005, 91, 131-137. [CrossRef] 
9. Murugan, K.; Murugan, P.; Noortheen, A. Larvicidal and repellent potential of Albizzia amara Boivin and Ocimum basilicum Linn against dengue vector, Aedes aegypti (Insecta: Diptera: Culicidae). Bioresour. Technol. 2007, 98, 198-201. [CrossRef] [PubMed]

10. Vieira, R.F.; Simon, J.E. Chemical characterization of basil (Ocimum spp.) found in the markets and used in traditional medicine in Brazil. Econ. Bot. 2000, 54, 207-216. [CrossRef]

11. Sajjadi, S.E. Analysis of the essential oils of two cultivated basil (Ocimum basilicum L.) from Iran. DARU J. Pharm. Sci. 2006, 14, 128-130.

12. Avetisyan, A.; Markosian, A.; Petrosyan, M.; Sahakyan, N.; Babayan, A.; Aloyan, S.; Trchounian, A. Chemical composition and some biological activities of the essential oils from basil Ocimum different cultivars. BMC Complement. Altern. Med. 2017, 17, 60. [CrossRef] [PubMed]

13. Smith, R.; Adams, T.; Doull, J.; Feron, V.; Goodman, J.; Marnett, L.; Portoghese, P.; Waddell, W.; Wagner, B.; Rogers, A. Safety assessment of allylalkoxybenzene derivatives used as flavouring substances-methyl eugenol and estragole. Food Chem. Toxicol. 2002, 40, 851-870. [CrossRef]

14. Wallace, L.A.; Nelson, W.C.; Raymer, J.H.; Thomas, K.W. Identification of Polar Volatile Organic Compounds in Consumer Products and Common Microenvironments; EPA: Washington, DC, USA, 1991.

15. McCree, K.J. Test of current definitions of photosynthetically active radiation against leaf photosynthesis data. Agric. For. Meteorol. 1972, 10, 443-453. [CrossRef]

16. Gallo, K.; Daughtry, C. Techniques for measuring intercepted and absorbed Photosynthetically Active Radiation in Corn Canopies 1. Agron. J. 1986, 78, 752-756. [CrossRef]

17. Britton, C.; Dodd, J. Relationships of photosynthetically active radiation and shortwave irradiance. Agric. Meteorol. 1976, 17, 1-7. [CrossRef]

18. Sims, D.A.; Gamon, J.A. Relationships between leaf pigment content and spectral reflectance across a wide range of species, leaf structures and developmental stages. Remote Sens. Environ. 2002, 81, 337-354. [CrossRef]

19. Mitchell, C.A.; Both, A.-J.; Bourget, C.; Burr, J.; Kubota, C.; Lopez, R.; Morrow, R.; Runkle, E. LEDs: The future of greenhouse lighting! Chron. Hortic. 2012, 52, 6-12.

20. Singh, D.; Basu, C.; Meinhardt-Wollweber, M.; Roth, B. LEDs for energy efficient greenhouse lighting. Renew. Sustain. Energy Rev. 2015, 49, 139-147. [CrossRef]

21. Jensen, N.B.; Clausen, M.R.; Kjaer, K.H. Spectral quality of supplemental LED grow light permanently alters stomatal functioning and chilling tolerance in basil (Ocimum basilicum L.). Sci. Hortic. 2018, 227, $38-47$. [CrossRef]

22. Nelson, J.A.; Bugbee, B. Economic analysis of greenhouse lighting: Light emitting diodes vs. high intensity discharge fixtures. PLoS ONE 2014, 9, e99010. [CrossRef] [PubMed]

23. Bula, R.J.; Morrow, R.C.; Tibbitts, T.W.; Barta, D.J.; Ignatius, R.W.; Martin, T.S. Light-emitting diodes as a radiation source for plants. HortScience 1991, 26, 203-205. [CrossRef] [PubMed]

24. Bosma, R.H.; Lacambra, L.; Landstra, Y.; Perini, C.; Poulie, J.; Schwaner, M.J.; Yin, Y. The financial feasibility of producing fish and vegetables through aquaponics. Aquac. Eng. 2017, 78, 146-154. [CrossRef]

25. Van Ieperen, W.; Trouwborst, G. The application of LEDs as assimilation light source in greenhouse horticulture: A simulation study. In Proceedings of the International Symposium on High Technology for Greenhouse System Management: Greensys2007, Naples, Italy, 4 October 2007; Volume 801, pp. 1407-1414.

26. Tonzani, S. Lighting technology: Time to change the bulb. Nat. News 2009, 459, 312-314. [CrossRef] [PubMed]

27. Brown, C.S.; Schuerger, A.C.; Sager, J.C. Growth and photomorphogenesis of pepper plants under red light-emitting diodes with supplemental blue or far-red lighting. J. Am. Soc. Hortic. Sci. 1995, 120, 808-813. [CrossRef] [PubMed]

28. Lin, K.-H.; Huang, M.-Y.; Huang, W.-D.; Hsu, M.-H.; Yang, Z.-W.; Yang, C.-M. The effects of red, blue, and white light-emitting diodes on the growth, development, and edible quality of hydroponically grown lettuce (Lactuca sativa L. var. capitata). Sci. Hortic. 2013, 150, 86-91.

29. Goins, G.D.; Yorio, N.; Sanwo, M.; Brown, C. Photomorphogenesis, photosynthesis, and seed yield of wheat plants grown under red light-emitting diodes (LEDs) with and without supplemental blue lighting. J. Exp. Bot. 1997, 48, 1407-1413. [CrossRef] [PubMed]

30. Kim, S.-J.; Hahn, E.-J.; Heo, J.-W.; Paek, K.-Y. Effects of LEDs on net photosynthetic rate, growth and leaf stomata of chrysanthemum plantlets in vitro. Sci. Hortic. 2004, 101, 143-151. [CrossRef] 
31. Saha, S.; Monroe, A.; Day, M.R. Growth, yield, plant quality and nutrition of basil (Ocimum basilicum L.) under soilless agricultural systems. AOAS 2016, 61, 181-186. [CrossRef]

32. Burbott, A.J.; Loomis, W.D. Effects of light and temperature on the monoterpenes of peppermint. Plant Physiol. 1967, 42, 20-28. [CrossRef] [PubMed]

33. Zhao, L. Steam alternating solvent process. In Proceedings of the SPE International Thermal Operations and Heavy Oil Symposium and Western Regional Meeting, Bakersfield, CA, USA, 16-18 March 2004.

34. Joshi, R.K. Chemical composition and antimicrobial activity of the essential oil of Ocimum basilicum L.(sweet basil) from Western Ghats of North West Karnataka, India. Anc. Sci. Life 2014, 33, 151. [CrossRef] [PubMed]

35. Calín-Sánchez, Á.; Lech, K.; Szumny, A.; Figiel, A.; Carbonell-Barrachina, Á.A. Volatile composition of sweet basil essential oil (Ocimum basilicum L.) as affected by drying method. Food Res. Int. 2012, 48, 217-225. [CrossRef]

36. Leal, P.F.; Maia, N.B.; Carmello, Q.A.; Catharino, R.R.; Eberlin, M.N.; Meireles, M.A.A. Sweet basil (Ocimum basilicum) extracts obtained by supercritical fluid extraction (SFE): Global yields, chemical composition, antioxidant activity, and estimation of the cost of manufacturing. Food Bioprocess Technol. 2008, 1, 326. [CrossRef]

37. Market, E.A. Global Industry Analysis, Size, Share, Growth, Trends and Forecast 2016-2024; Transparency Market Research Ltd.: Albany, NY, USA, 2017.

38. Chenni, M.; El Abed, D.; Rakotomanomana, N.; Fernandez, X.; Chemat, F. Comparative study of essential oils extracted from Egyptian basil leaves (Ocimum basilicum L.) using hydro-distillation and solvent-free microwave extraction. Molecules 2016, 21, 113. [CrossRef] [PubMed]

39. Kumari, R.; Agrawal, S. Comparative analysis of essential oil composition and oil containing glands in Ocimum sanctum L. (Holy basil) under ambient and supplemental level of UV-B through gas chromatography-mass spectrometry and scanning electron microscopy. Acta Physiol. Plant 2011, 33, 1093-1101. [CrossRef]

40. Gómez, C.; Morrow, R.C.; Bourget, C.M.; Massa, G.D.; Mitchell, C.A. Comparison of intracanopy light-emitting diode towers and overhead high-pressure sodium lamps for supplemental lighting of greenhouse-grown tomatoes. HortTechnology 2013, 23, 93-98. [CrossRef]

41. Randall, W.C.; Lopez, R.G. Comparison of supplemental lighting from high-pressure sodium lamps and light-emitting diodes during bedding plant seedling production. HortScience 2014, 49, 589-595. [CrossRef]

42. Currey, C.J.; Lopez, R.G. Cuttings of Impatiens, Pelargonium, and Petunia propagated under light-emitting diodes and high-pressure sodium lamps have comparable growth, morphology, gas exchange, and post-transplant performance. HortScience 2013, 48, 428-434. [CrossRef]

43. Pimputkar, S.; Speck, J.S.; DenBaars, S.P.; Nakamura, S. Prospects for LED lighting. Nat. Photonics 2009, 3, 180. [CrossRef]

44. Chen, M.; Chory, J. Phytochrome signaling mechanisms and the control of plant development. Trends Cell Biol. 2011, 21, 664-671. [CrossRef] [PubMed]

45. Darko, E.; Heydarizadeh, P.; Schoefs, B.; Sabzalian, M.R. Photosynthesis under artificial light: The shift in primary and secondary metabolism. Philos. Trans. R. Soc. 2014, 369, 20130243. [CrossRef] [PubMed]

46. Assmann, S.M.; Shimazaki, K. The multisensory guard cell. Stomatal responses to blue light and abscisic acid. Plant Physiol. 1999, 119, 809-816. [CrossRef] [PubMed]

47. Doi, M.; Kitagawa, Y.; Shimazaki, K.-I. Stomatal blue light response is present in early vascular plants. Plant Physiol. 2015, 169, 1205-1213. [CrossRef] [PubMed]

48. Inoue, S.-I.; Kinoshita, T. Blue light regulation of stomatal opening and the plasma membrane H+-ATPase. Plant Physiol. 2017. [CrossRef] [PubMed]

49. Tennessen, D.J.; Singsaas, E.L.; Sharkey, T.D. Light-emitting diodes as a light source for photosynthesis research. Photosynth. Res. 1994, 39, 85-92. [CrossRef] [PubMed]

50. Baker, N.R.; Oxborough, K. Chlorophyll fluorescence as a probe of photosynthetic productivity. In Chlorophyll A Fluorescence; Springer: Berlin, Germany, 2004; pp. 65-82.

51. Strasser, R.J.; Srivastava, A.; Tsimilli-Michael, M. The Fluorescence Transient as A Tool to Characterize and Screen Photosynthetic Samples; CRC Press: Boca Raton, FL, USA, 2000; pp. 445-483.

52. Wang, Z.; Tian, J.; Yu, B.; Yang, L.; Sun, Y. LED light spectrum affects the photosynthetic performance of Houttuynia Cordata seedlings. Am. J. Opt. Photonics 2015, 3, 38-42. [CrossRef] 
53. Naznin, M.T.; Lefsrud, M.; Gravel, V.; Azad, M.O.K. Blue Light added with Red LEDs Enhance Growth Characteristics, Pigments Content, and Antioxidant Capacity in Lettuce, Spinach, Kale, Basil, and Sweet Pepper in a Controlled Environment. Plants 2019, 8, 93. [CrossRef] [PubMed]

54. Muneer, S.; Kim, E.; Park, J.; Lee, J. Influence of green, red and blue light emitting diodes on multiprotein complex proteins and photosynthetic activity under different light intensities in lettuce leaves (Lactuca sativa L.). Int. J. Mol. Sci. 2014, 15, 4657-4670. [CrossRef] [PubMed]

55. Lurie, S. The effect of wavelength of light on stomatal opening. Planta 1978, 140, 245-249. [CrossRef] [PubMed]

56. Sharkey, T.D.; Raschke, K. Effect of light quality on stomatal opening in leaves of Xanthium strumarium L. Plant Physiol. 1981, 68, 1170-1174. [CrossRef] [PubMed]

57. Pennisi, G.; Blasioli, S.; Cellini, A.; Maia, L.; Crepaldi, A.; Braschi, I.; Spinelli, F.; Nicola, S.; Fernandez, J.A.; Stanghellini, C. Unraveling the Role of Red: Blue LED Lights on Resource Use Efficiency and Nutritional Properties of Indoor Grown Sweet Basil. Front. Plant Sci. 2019, 10, 305. [CrossRef] [PubMed]

58. Scarth, G.W. Mechanism of the action of light and other factors on stomatal movement. Plant Physiol. 1932, 7, 481. [CrossRef] [PubMed]

59. Webber, A.N.; Lubitz, W. P700: The primary electron donor of photosystem I. BBA 2001, 1507, 61-79. [CrossRef]

60. Durrant, J.R.; Klug, D.R.; Kwa, S.; Van Grondelle, R.; Porter, G.; Dekker, J.P. A multimer model for P680, the primary electron donor of photosystem II. Proc. Natl. Acad. Sci. USA 1995, 92, 4798-4802. [CrossRef] [PubMed]

61. Dougher, T.A.; Bugbee, B.G. Is blue light good or bad for plants? Life Support Biosph. Sci. 1998, 5, 129-136. [PubMed]

62. Dou, H.; Niu, G.; Gu, M.; Masabni, J. Effects of light quality on growth and phytonutrient accumulation of herbs under controlled environments. Horticulturae 2017, 3, 36. [CrossRef]

63. Gök, K.M.; Bekir, Ş.; Bayhan, A.K. Micropropagation of Gerbera (Gerbera jamesonii Bolus) under Different Color of Light-Emitting Diodes. Süleyman Demirel Üniversitesi Fen Bilimleri Enstitüsü Dergisi 2016, 20, 468-474. [CrossRef]

64. Kim, H.-H.; Goins, G.D.; Wheeler, R.M.; Sager, J.C. Green-light supplementation for enhanced lettuce growth under red-and blue-light-emitting diodes. HortScience 2004, 39, 1617-1622. [CrossRef] [PubMed]

65. Ménard, C.; Dorais, M.; Hovi, T.; Gosselin, A. Developmental and physiological responses of tomato and cucumber to additional blue light. In Proceedings of the V International Symposium on Artificial Lighting in Horticulture, Lillehammer, Norway, 30 June 2006; pp. 291-296.

66. Amaki, W.; Yamazaki, N.; Ichimura, M.; Watanabe, H. Effects of Light Quality on the Growth and Essential Oil Content in Sweet Basil. Acta Hortic. 2011, 907, 91-94. [CrossRef]

67. Fahlén, A.; Welander, M.; Wennersten, R. Effects of light-temperature regimes on plant growth and essential oil yield of selected aromatic plants. J. Sci. Food Agric. 1997, 73, 111-119. [CrossRef]

68. Chang, X. Effect of Light and Temperature on Volatile Compounds and Growth Parameters in Sweet Basil (Ocimum basilicum L.). Ph.D. Thesis, University of Nottingham, Nottingham, UK, 2005.

69. Skrubis, B.; Markakis, P. The effect of photoperiodism on the growth and the essential oil of Ocimum basilicum (sweet basil). Econ. Bot. 1976, 30, 389. [CrossRef]

(C) 2019 by the authors. Licensee MDPI, Basel, Switzerland. This article is an open access article distributed under the terms and conditions of the Creative Commons Attribution (CC BY) license (http://creativecommons.org/licenses/by/4.0/). 